\title{
SUSCEPTIBILITY OF SOME SUNFLOWER CULTIVARS FOR PIERCING SUCKING PESTS IN SOHAG GOVERNORATE
}

\author{
AZZA A. MOHAMED and SAFAA M. ABD EL-AZIZ \\ Plant Protection Research Institute, ARC, Dokki, Giza
}

(Manuscript received 25 March 2012)

\begin{abstract}
This study was carried out to evaluate the susceptibility of certain cultivars of sunflower crop ( Giza 102, Pioneer6480, Sakha 53 and Miak) to certain piercing sucking pests' infestation under field conditions for two successive seasons (2010 \& 2011) in Sohag governorate, Egypt.

Data revealed that the tested sunflower cultivars have marked variation in their susceptibility to pest infestation. Giza102 \& Sakha 53 cultivars were the most susceptible for $E$. decipiens nymphs and $M$. persicae pests infestation as it showed a mean number of 18.07 \& 18.4 nymphs/15 leaflet \& 4.89, 2.07 individual/15 sunflower leaflet followed by, Miak \& pioneer6480 during 2010 season, a similar trend was obtained for two pests in 2011. On the other hand, the resistant cultivars to the whitefly infestation could be arranged in ascending as follow: Sakha 53, Giza 102, Miak and Pioneer6480 \&. The corresponding infestation rates averaged 49.07, 51.59, 66.52 and $70.96 \& 53.67,55.26$, $62.11,69.78 \mathrm{nymph} / 15$ leafletlets, during 2010 and 2011 seasons, respectively.

Concerning susceptibility of sunflower cultivars to , Eutetranycus arabicus infestation statistical analysis revealed that Miak was highly significantl while Giza 102 was less significantly infested in both seasons, meanwhile in T. urticae, the cultivar Pioneer6480 proved to be susceptible than all cultivars with averarge 91.78 and 96.56 individuals/ 15 sunflower leaflets in 2010 and 2011 seasons, respectively; while, Sakha 53 cultivar harboured significantly a lower infestation with average numbers of 46.19 and 57.81 individuals/ 15 sunflower leaflets in 2010 and 2011 seasons, respectively. Regarding to predator mite, Euseius hutu Giza 102 was the most susceptible in two seasons.
\end{abstract}

\section{INTRODUCTION}

Sunflower plant is widely cultivated in many parts of the world as major and strategy oil crop.

Sunflower crop (Helianthus annus) is considered an important host to a huge number of insect pests (Charlet and Brewer, 1998); however there is a considerable variation in the respective importance of the different pests in different countries. In the meantime, productivity is rather limited due to many factors i.e. variety, agricultural practices and their consequent influence in the pest complex in the field. 
On the other hand, several reports showed that agricultural practices, natural enemies, and varietals resistance, proved to be effective factors in decreasing the population of such pests and their damage to crops( Charlet and Knodel. 2003). The main pests attacking legume vegetables have been reported to include Empoasca decipiens (Paoli) (Cicadellidae: Homoptera), Bemisia tabaci (Genn.) (Alyerodidae: Homoptera), Myzus persicae (Sulz.) (Aphididae: Homoptera).

So, the present study was conducted to investigate the following points:

1. The population densities of certain piercing and sucking pests attacking this crop.

2. The population densities of the predators associated with piercing sucking pests attacking sunflower crop.

3. The relationship between the piercing sucking pests and their associated predators.

4. The relative susceptibility of some sunflower crop varieties to certain piercing sucking pests' infestation.

5. Effect of certain climatic factors on the population densities of piercing and sucking pests.

\section{MATERIALS AND METHODS}

The present study was conducted at the farm of Shandweel Agricultural Research Station, Sohag governorate, Egypt, during the two successive seasons (2010) and (2011). An area of about 1/4 Feddan was divided into plots of equal size (1/100 feddan) and arranged in completely randomized blocks with three replicates.

Throughout the summer season sunflower seeds were sowing in the last week of May on one side of the ridge at $20 \mathrm{~cm}$ spacing. Four sunflower cultivars were put under investigation, i.e., Giza 102, Pioneer6480, Sakha 53 and Miak.

No pesticides were used in experimental time.

Samples of 15 leaves were randomly selected weekly from upper, middle and lower level of sunflower plants per each plot. Samples started after 15 days from sowing date then continued to harvesting. The selected samples were transferred to the laboratory for inspection with stereomicroscope to determine the number of Myzus persicae (Sulz.), Emoasca decipiens (Paoli) (nymphs), and Bemisia tabaci (Genn.) (nymphs), Tetranychus urticae Koch and Eutetranycus arabicus (Acari: Tetranychidae).

Data obtained were statistically analyzed using one - way analysis of variance. Mean values were separated by the least significant difference (L.S.D.) procedure at $P=5 \%$. Simple correlation $(r)$ between the number of sucking insect pests and the total number of associated predators was calculated 


\section{RESULTS AND DISCUSSION}

The relative susceptibility of some sunflower crop varieties (Giza 102, Pioneer6480, Sakha 53 and Miak) to certain piercing sucking pests' infestation in Sohag governorate, Egypt, during the two successive seasons (2010) and (2011) were investigated.

\section{(1): Emoasca decipiens}

Tables (1) \& Fig. (1) present the mean number of nymphs per 15 sunflower leaves in 2010 and 2011 seasons. In 2010 season, the pest nymph individuals were observed from the beginning of inspection period, increased gradually and showed one peak of activity in all cultivars in 7/ July for Giza 102, Sakha 53 and Miak with average number of $57.67,50.67$ and 34.67 nymphs/ 15 sunflower leaflet, respectively, and in 14/ July for Pioneer6480 with average number of 34.67 nymphs/ 15 sunflower leaflets. Then the number decreased gradually to the end of the season.

However, in 2011 season, the first appearance of the pest observed in 16/ June with a highly numbers in Pioneer6480, Sakha 53 and Miak plots then decreased in the next week. Then the numbers increased gradually to form one peak in $7 /$ July with average numbers of $64.33,61.33$ and 36.00 nymphs/ 15 sunflower leaflets, respectively, and 14/ July for Pioneer6480 with average number of 35.00 nymphs/ 15 sunflower leaflets. Afterthat, the numbers decreased gradually to disappear completely in the last week of inspection period.

For the susceptibility of sunflower cultivar to E. decipiens infestation, data showed that cultivars Giza 102 and Sakha 53 received highly significant mean numbers of pest nymphs with mean numbers of 18.07 and 18.74 nymphs/ 15 sunflower leaflets, respectively, while Pioneer6480 and Miak showed significantly lower infestation with mean numbers of 11.93 and 11.11 nymphs/ 15 sunflower leaflets, respectively, in 2010 season. While, In 2011 season, a similar trend was obtained with mean number of 22.33, 13.52, 21.56 and 14.37 nymphs/ 15 sunflowers leaflet, respectively. 
Table 1.Mean number of $E$. decipiens nymphs attacking sunflower cultivar, Sohag Governorate, 2010 and 2011 seasons.

\begin{tabular}{|c|c|c|c|c|c|c|c|c|}
\hline \multicolumn{9}{|c|}{ Mean No./ 15 leaflet } \\
\hline \multirow[t]{2}{*}{ Date } & \multicolumn{4}{|c|}{2010 season } & \multicolumn{4}{|c|}{2011 season } \\
\hline & $\begin{array}{c}\text { Giza } \\
102 \\
\end{array}$ & $\begin{array}{c}\text { Pioneer } \\
6480 \\
\end{array}$ & $\begin{array}{c}\text { Sakha } \\
53 \\
\end{array}$ & Miak & $\begin{array}{l}\text { Giza } \\
102 \\
\end{array}$ & $\begin{array}{c}\text { Pioneer } \\
6480 \\
\end{array}$ & $\begin{array}{c}\text { Sakha } \\
53 \\
\end{array}$ & Miak \\
\hline $\begin{array}{c}\text { Jun } \\
9\end{array}$ & 0.67 & 0.33 & 1.67 & 1.67 & 0.00 & 0.00 & 0.00 & 0.00 \\
\hline 16 & 7.00 & 3.33 & 8.00 & 5.00 & 6.33 & 12.00 & 16.00 & 16.33 \\
\hline 23 & 11.67 & 7.33 & 11.33 & 8.67 & 13.67 & 8.33 & 12.67 & 13.33 \\
\hline 30 & 27.00 & 12.67 & 28.00 & 13.33 & 31.67 & 17.67 & 34.33 & 21.33 \\
\hline $\begin{array}{l}\text { Jul } \\
7 \\
\end{array}$ & 57.67 & 21.33 & 50.67 & 34.67 & 64.33 & 26.33 & 61.33 & 36.00 \\
\hline 14 & 25.00 & 34.67 & 35.67 & 22.00 & 46.00 & 35.00 & 38.33 & 25.00 \\
\hline 21 & 23.00 & 15.33 & 17.33 & 8.00 & 30.67 & 14.67 & 18.67 & 11.00 \\
\hline 28 & 10.00 & 10.00 & 15.33 & 5.33 & 8.33 & 7.67 & 12.67 & 6.33 \\
\hline $\begin{array}{c}\text { Aug } \\
4 \\
\end{array}$ & 0.67 & 2.33 & 0.67 & 1.33 & 0.00 & 0.00 & 0.00 & 0.00 \\
\hline Mean & 18.07 & 11.93 & 18.74 & 11.11 & 22.33 & 13.52 & 21.56 & 14.37 \\
\hline F-value & \multicolumn{4}{|c|}{30.00} & \multicolumn{4}{|c|}{57.23} \\
\hline LSD 0.05 & \multicolumn{4}{|c|}{2.38} & \multicolumn{4}{|c|}{2.00} \\
\hline
\end{tabular}

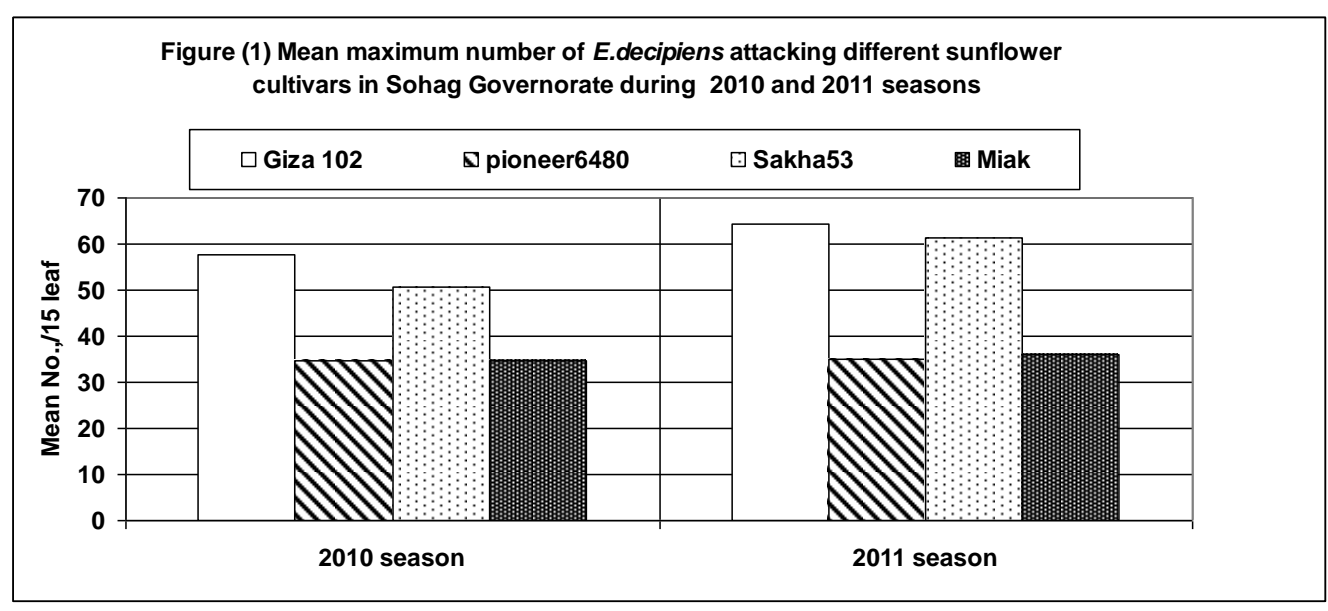




\section{(2): Bemisia tabaci:}

Data given in Table (2) \& Fig. (2) showed the mean number of B. tabaci nymphs detected in all sampling dates of the two seasons. The whitefly nymphs appeared with relatively high numbers recorded their peak in 30/ June for Giza 102 and Pioneer6480 with average numbers of 110,00 and 140.67 nymphs/ 15 sunflower leaflets, respectively, and in 7/ July for Sakha 53 and Miak with average numbers of 106, 00 and 152.33 nymphs/ 15 sunflower leaflets, respectively, then the number decreased gradually to the end of 2010 season. In 2011 season, the pest reached their maximum numbers in 30/ June with average number of 139.67 nymphs/ 15 sunflower leaflets, and in 7/ July for Giza 102, Sakha 53 and Miak with average numbers of $133.00,113.67$ and 153.67 nymphs/ 15 sunflowers leaflets, respectively. From the above data, it's clear that the differences between cultivars were significant in both seasons. Pioneer6480 and Miak cultivars were found to be the most susceptible with average numbers of 70.96 and 66.52 nymphs/ 15 sunflower leaflets, respectively, in 2010 season and 69.78 and 62.11 nymphs/ 15 sunflower leaflets, respectively, in 2011 season. On the other hand, cultivars Giza 102 and Sakha 53 harbored significantly lower infestation in both seasons with average numbers of 51.59 and 49.07 nymphs/ 15 sunflower leaflets, respectively, in 2010 season and 55.26 and 53.67 nymphs/ 15 sunflower leaflets, respectively.

Table 2. Mean number of $B$. tabaci nymphs attacking sunflower cultivar, Sohag Governorate, 2010 and 2011 seasons.

\begin{tabular}{|c|c|c|c|c|c|c|c|c|}
\hline \multicolumn{9}{|c|}{ Mean No./ 15 leaflets } \\
\hline \multirow[b]{2}{*}{ Date } & \multicolumn{4}{|c|}{2010 season } & \multicolumn{4}{|c|}{2011 season } \\
\hline & $\begin{array}{l}\text { Giza } \\
102\end{array}$ & $\begin{array}{c}\text { Pioneer } \\
6480\end{array}$ & $\begin{array}{c}\text { Sakha } \\
53\end{array}$ & Miak & $\begin{array}{l}\text { Giza } \\
102\end{array}$ & $\begin{array}{c}\text { Pioneer } \\
6480\end{array}$ & $\begin{array}{c}\text { Sakha } \\
53\end{array}$ & Miak \\
\hline $\begin{array}{c}\text { Jun } \\
9\end{array}$ & 23.67 & 33.67 & 11.33 & 28.67 & 18.67 & 11.33 & 16.00 & 10.33 \\
\hline 16 & 57.00 & 81.67 & 38.33 & 59.33 & 47.33 & 72.00 & 33.33 & 28.33 \\
\hline 23 & 63.67 & 102.00 & 73.00 & 88.67 & 57.33 & 97.00 & 87.00 & 92.00 \\
\hline 30 & 110.00 & 140.67 & 97.67 & 120.00 & 89.67 & 139.67 & 104.67 & 116.67 \\
\hline $\begin{array}{c}\text { Jul } \\
7\end{array}$ & 79.00 & 118.67 & 106.00 & 152.33 & 133.00 & 123.00 & 113.00 & 153.67 \\
\hline 14 & 54.00 & 65.67 & 63.67 & 89.00 & 61.67 & 79.67 & 69.00 & 93.67 \\
\hline 21 & 43.67 & 53.67 & 30.00 & 38.67 & 54.00 & 63.00 & 35.33 & 36.67 \\
\hline 28 & 30.67 & 37.33 & 17.67 & 19.33 & 26.00 & 38.00 & 20.33 & 22.00 \\
\hline $\begin{array}{c}\text { Aug } \\
4\end{array}$ & 2.67 & 5.33 & 4.00 & 2.67 & 9.67 & 4.33 & 4.33 & 5.67 \\
\hline Mean & 51.59 & 70.96 & 49.07 & 66.52 & 55.26 & 69.78 & 53.67 & 62.11 \\
\hline F-value & \multicolumn{4}{|c|}{31.82} & \multicolumn{4}{|c|}{8.24} \\
\hline LSD $\quad 0.05$ & \multicolumn{4}{|c|}{6.261} & \multicolumn{4}{|c|}{8.36} \\
\hline
\end{tabular}




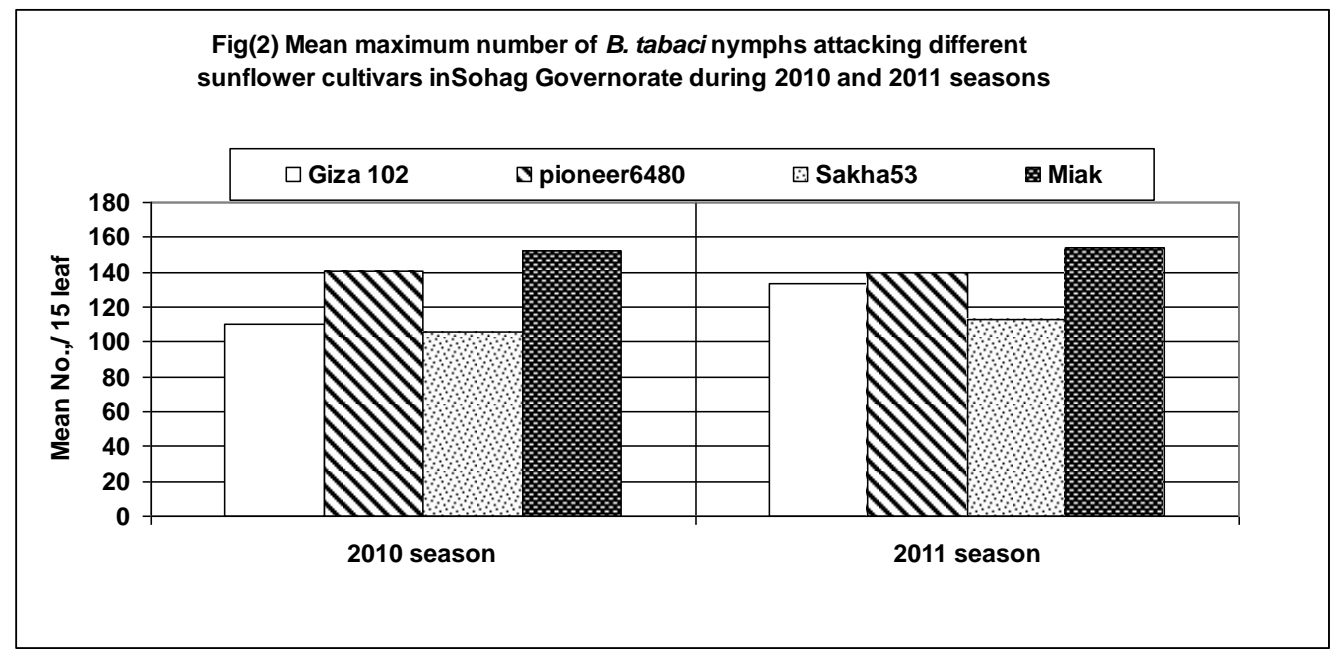

\section{(3): Myzus, persicae:}

The population density of $M$. persicae individuals is summarized in Table (3) \& Fig (3). M. persicae started to colonize on sunflower plants in $7 /$ July in both seasons of the study. One peak of activity was achieved in all cultivars in both seasons. The aphid gave their maximum number in 21/ July for Giza 102, Sakha 53 and Miak with average numbers of 21.67, 9.67 and 7.33 nymphs/ 15 sunflower leaflet, respectively, and in 14/ July for Pioneer6480 with average number of 6.33 nymphs/ 15 sunflower leaflets in the first season. Also, the peak of activity was recorded in 14/ July for all cultivars with average numbers of 13.00, 11.33, 13.67 and 13.33 nymphs/ 15 sunflower leaflets, respectively, in the second season.

Concerning the susceptibility of four sunflower cultivars, Giza 102 was the most susceptible one with average number of 4.89 nymphs/ 15 sunflowers leaflet. while, Giza 102, Sakha 53 and Miak cultivars received 1.74, 2.07 and 1.70 nymphs/ 15 sunflowers leaflet, respectively in 2010 season. However, the obtained data revealed that the differences between cultivars were insignificant in 2011 season, with average numbers of $1.63,2.56,3.15$ and 2.30 nymphs/ 15 sunflower leaflets, respectively. 
Table 3. Mean number of $M$. persicae individuals attacking sunflower cultivar, Sohag Governorate, 2010 and 2011 seasons.

\begin{tabular}{|c|c|c|c|c|c|c|c|c|}
\hline \multicolumn{9}{|c|}{ Mean No./ 15 leavs } \\
\hline \multirow[t]{2}{*}{ Date } & \multicolumn{4}{|c|}{2010 season } & \multicolumn{4}{|c|}{2011 season } \\
\hline & $\begin{array}{c}\text { Giza } \\
102\end{array}$ & $\begin{array}{c}\text { Pionee } \\
\text { r6480 }\end{array}$ & $\begin{array}{c}\text { Sakha } \\
53\end{array}$ & Miak & $\begin{array}{l}\text { Giza } \\
102\end{array}$ & $\begin{array}{c}\text { Pionee } \\
\text { r6480 }\end{array}$ & $\begin{array}{c}\text { Sakha } \\
53\end{array}$ & Miak \\
\hline $\begin{array}{c}\text { Jun } \\
9\end{array}$ & 0.00 & 0.00 & 0.00 & 0.00 & 0.00 & 0.00 & 0.00 & 0.00 \\
\hline 16 & 0.00 & 0.00 & 0.00 & 0.00 & 0.00 & 0.00 & 0.00 & 0.00 \\
\hline 23 & 0.00 & 0.00 & 0.00 & 0.00 & 0.00 & 0.00 & 0.00 & 0.00 \\
\hline 30 & 0.00 & 0.00 & 0.00 & 0.00 & 0.00 & 0.00 & 0.00 & 0.00 \\
\hline $\begin{array}{c}\text { Jul } \\
7\end{array}$ & 1.00 & 1.00 & 1.33 & 0.67 & 1.67 & 3.33 & 7.67 & 2.33 \\
\hline 14 & 6.00 & 6.33 & 5.67 & 6.67 & 13.00 & 11.33 & 13.67 & 13.33 \\
\hline 21 & 21.67 & 4.00 & 9.67 & 7.33 & 0.00 & 6.33 & 5.00 & 4.00 \\
\hline 28 & 10.67 & 2.33 & 2.00 & 0.67 & 0.00 & 2.00 & 2.00 & 1.00 \\
\hline $\begin{array}{c}\text { Aug } \\
4\end{array}$ & 4.67 & 2.00 & 0.00 & 0.00 & 0.00 & 0.00 & 0.00 & 0.00 \\
\hline Mean & 4.89 & 1.74 & 2.07 & 1.70 & 1.63 & 2.56 & 3.15 & 2.30 \\
\hline F-value & \multicolumn{4}{|c|}{14.29} & & & & \\
\hline $\begin{array}{l}\text { LSD } \\
0.05\end{array}$ & \multicolumn{4}{|c|}{1.32} & & & & \\
\hline
\end{tabular}

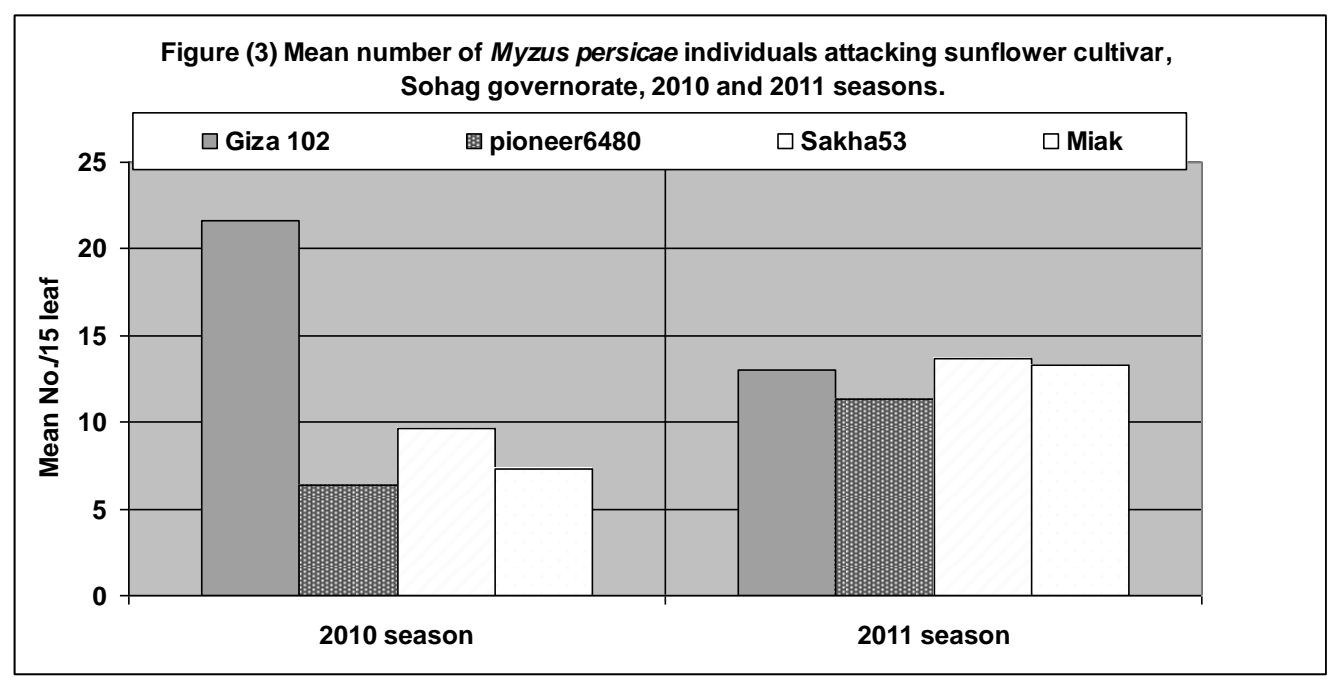




\section{(4): Eutetranycus arabicus}

The weekly average number of Eutetranycus arabicus population in sunflower plants of 2010 and 2011 seasons was shown in Tables (4) and fig. (4).

Eutetranycus arabicus individuals were recorded from the first date of inspection period and continued to the end of this inspection period during the two seasons. The numbers of the pest increased gradually to form two peaks on all cultivars in both seasons. In 2010 season, Giza 102 and Pioneer6480 achieved 60.33, 137.00 individuals/ 15 sunflower leaflets, respectively in 23/ July, and 113.00 and 233.00, respectively, in 21/ July. Also, the pest recorded 110.33 and 237.00 individuals/ 15 sunflower leaflets in Sakha 53 and Miak cultivars, respectively, in 30/ June, and 150.33 and 305.33 individuals/ 15 sunflower leaflets in the same cultivars, respectively, in $21 /$ July.

In 2011 season, the pest recorded 73.67, 129.67, 65.67 and 109.33 individuals/ 15 sunflowers leaflets in 23/ June for Giza 102, Pioneer6480, Sakha 53 and Miak, respectively and 99.00, 122.00, 169.00 and 200.00 individuals/ 15 sunflower leaflets in 21 / July for the same cultivars, respectively.

In regard to susceptibility of sunflower cultivars to Earabicus infestation, the statistical analysis revealed that the cultivar Miak was significantly more infested by the E. arabicus than all tested cultivars, however, cultivar Giza 102 was significantly less infested in both seasons. As, Giza 102, Pioneer6480, Sakha 53 and Miak cultivars received 41.22, 82.11, 70.74 and 109.04 individuals/ 15 sunflower leaflets, respectively, in 2010 season, and 51.59, 76.89, 73.63 and 95.93 individuals/ 15 sunflower leaflets, respectively, in 2011 season. 
Table 4. Mean number of Eutetranycus arabicus individuals attacking sunflower cultivar, Sohag Governorate, 2010 and 2011 seasons.

\begin{tabular}{|c|c|c|c|c|c|c|c|c|}
\hline \multicolumn{9}{|c|}{ Mean No./ 15 leaflets } \\
\hline \multirow[t]{2}{*}{ Date } & \multicolumn{4}{|c|}{2010 season } & \multicolumn{4}{|c|}{2011 season } \\
\hline & $\begin{array}{l}\text { Giza } \\
102\end{array}$ & $\begin{array}{c}\text { Pioneer } \\
6480 \\
\end{array}$ & $\begin{array}{c}\text { Sakha } \\
53\end{array}$ & Miak & $\begin{array}{l}\text { Giza } \\
102 \\
\end{array}$ & $\begin{array}{c}\text { Pioneer } \\
6480 \\
\end{array}$ & $\begin{array}{c}\text { Sakha } \\
53\end{array}$ & Miak \\
\hline $\begin{array}{c}\text { Jun } \\
9\end{array}$ & 5.67 & 41.33 & 15.00 & 23.00 & 14.33 & 31.33 & 16.67 & 20.33 \\
\hline 16 & 10.33 & 73.67 & 42.00 & 65.00 & 54.33 & 85.33 & 52.00 & 79.67 \\
\hline 23 & 60.33 & 137.00 & 61.67 & 95.00 & 73.67 & 129.67 & 65.67 & 109.33 \\
\hline 30 & 24.67 & 91.33 & 110.33 & 237.00 & 39.33 & 89.00 & 52.33 & 87.67 \\
\hline $\begin{array}{c}\text { Jul } \\
7 \\
\end{array}$ & 18.67 & 55.00 & 59.67 & 27.00 & 24.67 & 63.67 & 83.00 & 88.67 \\
\hline 14 & 41.33 & 8.67 & 87.00 & 19.33 & 57.67 & 86.33 & 111.67 & 150.67 \\
\hline 21 & 113.00 & 233.00 & 150.33 & 305.33 & 99.00 & 122.00 & 169.00 & 200.00 \\
\hline 28 & 72.33 & 72.33 & 77.00 & 153.67 & 86.00 & 70.67 & 98.00 & 103.33 \\
\hline $\begin{array}{c}\text { Aug } \\
4\end{array}$ & 24.67 & 26.67 & 33.67 & 56.00 & 15.33 & 14.00 & 14.33 & 23.67 \\
\hline Mean & 41.22 & 82.11 & 70.74 & 109.04 & 51.59 & 76.89 & 73.63 & 95.93 \\
\hline F-value & \multicolumn{4}{|c|}{21.999} & \multicolumn{4}{|c|}{215.22} \\
\hline LSD $\quad 0.05$ & \multicolumn{4}{|c|}{19.53} & \multicolumn{4}{|c|}{4.04} \\
\hline
\end{tabular}

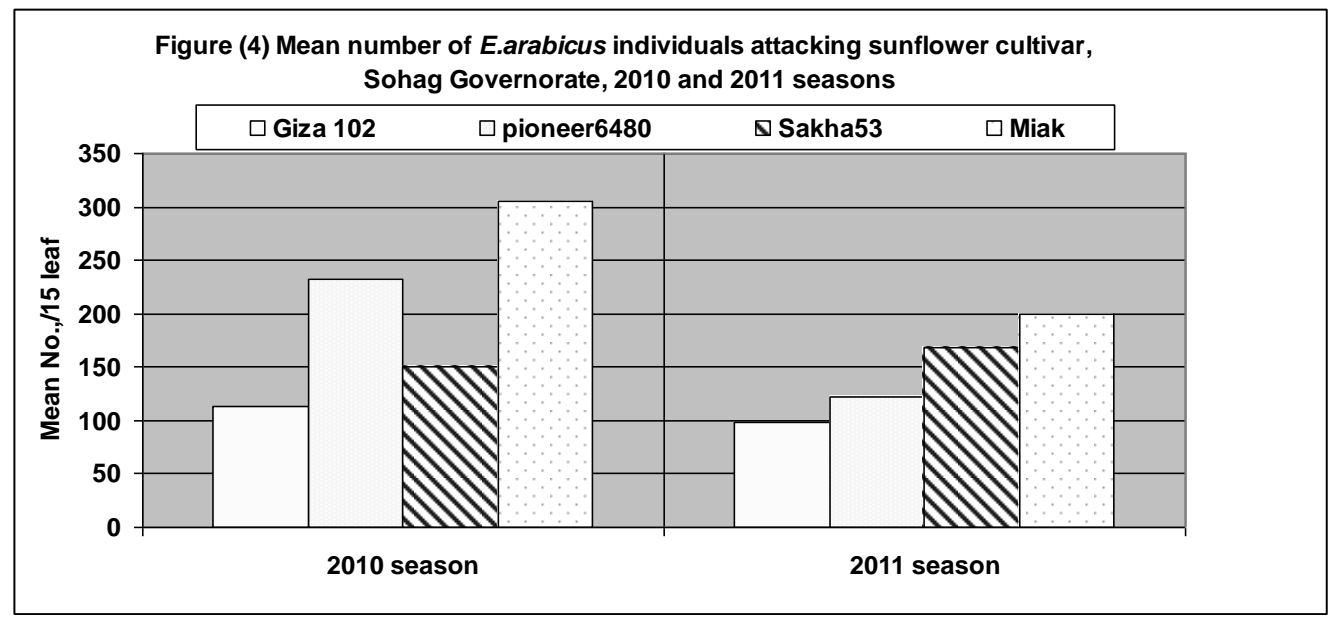




\section{(5): Tetranychus. urticae:}

T. urticae began to take place in sunflower fields in $16 /$ June, then the numbers increased gradually to reach their peak in 14/ July for Giza 102 and in 7/ July for the rest cultivars in 2010 season with average numbers of $121.00,298.00,158.33$ and 211.67 individuals/ 15 sunflower leaflets for Giza 102, Pioneer6480, Sakha 53 and Miak cultivars, respectively. Also, one peak was detected in the second season for all cultivars with average numbers of 218.00, 280.67, 175.00 and 217.67 individuals/ 15 sunflower leaflets for the mentioned cultivars, respectively. (table(5) \& Fig. (5))

Generally, the results indicated that cultivar Pioneer6480 proved to be susceptible than all cultivars in the two seasons of the study, because it harboured significantly the highest number of T. urticae individuals, 91.78 and 96.56 individuals/ 15 sunflower leaflets in 2010 and 2011 seasons, respectively. In addition, Sakha 53 cultivar harboured significantly a lower infestation than all cultivars in the two years of the study with average numbers of 46.19 and 57.81 individuals/ 15 sunflower leaflets in 2010 and 2011 seasons, respectively.

Table 5. Mean number of Tetranychus urticae attacking sunflower cultivar, Sohag Governorate, 2010 and 2011 seasons.

\begin{tabular}{|c|c|c|c|c|c|c|c|c|}
\hline \multicolumn{9}{|c|}{ Mean No./ 15 leaflets } \\
\hline \multirow[t]{2}{*}{ Date } & \multicolumn{4}{|c|}{2010 season } & \multicolumn{4}{|c|}{2011 season } \\
\hline & $\begin{array}{l}\text { Giza } \\
102\end{array}$ & $\begin{array}{c}\text { Pioneer } \\
6480\end{array}$ & $\begin{array}{c}\text { Sakha } \\
53\end{array}$ & Miak & $\begin{array}{l}\text { Giza } \\
102\end{array}$ & $\begin{array}{c}\text { Pioneer } \\
6480\end{array}$ & $\begin{array}{c}\text { Sakha } \\
53\end{array}$ & Miak \\
\hline $\begin{array}{c}\text { Jun } \\
9\end{array}$ & 0.00 & 0.00 & 0.00 & 0.00 & 0.00 & 0.00 & 0.00 & 0.00 \\
\hline 16 & 25.33 & 20.67 & 14.33 & 5.67 & 7.67 & 21.33 & 15.33 & 11.67 \\
\hline 23 & 50.67 & 77.33 & 32.00 & 31.67 & 42.67 & 94.00 & 37.33 & 35.67 \\
\hline 30 & 108.33 & 143.67 & 59.67 & 98.67 & 109.33 & 135.67 & 65.67 & 89.00 \\
\hline $\begin{array}{c}\text { Jul } \\
7\end{array}$ & 201.00 & 298.00 & 158.33 & 211.67 & 159.33 & 167.00 & 96.67 & 153.33 \\
\hline 14 & 121.00 & 163.33 & 75.00 & 123.00 & 218.00 & 280.67 & 175.00 & 217.67 \\
\hline 21 & 96.00 & 83.00 & 43.33 & 63.67 & 119.33 & 138.33 & 95.33 & 90.33 \\
\hline 28 & 60.33 & 39.33 & 27.33 & 27.33 & 36.00 & 23.33 & 21.33 & 19.67 \\
\hline $\begin{array}{c}\text { Aug } \\
4\end{array}$ & 15.33 & 0.67 & 5.67 & 10.67 & 5.33 & 8.67 & 13.67 & 5.33 \\
\hline Mean & 75.33 & 91.78 & 46.19 & 63.59 & 77.52 & 96.56 & 57.81 & 69.19 \\
\hline F-value & \multicolumn{4}{|c|}{23.19} & \multicolumn{4}{|c|}{51.37} \\
\hline LSD $\quad 0.05$ & \multicolumn{4}{|c|}{13.02} & \multicolumn{4}{|c|}{7.43} \\
\hline
\end{tabular}




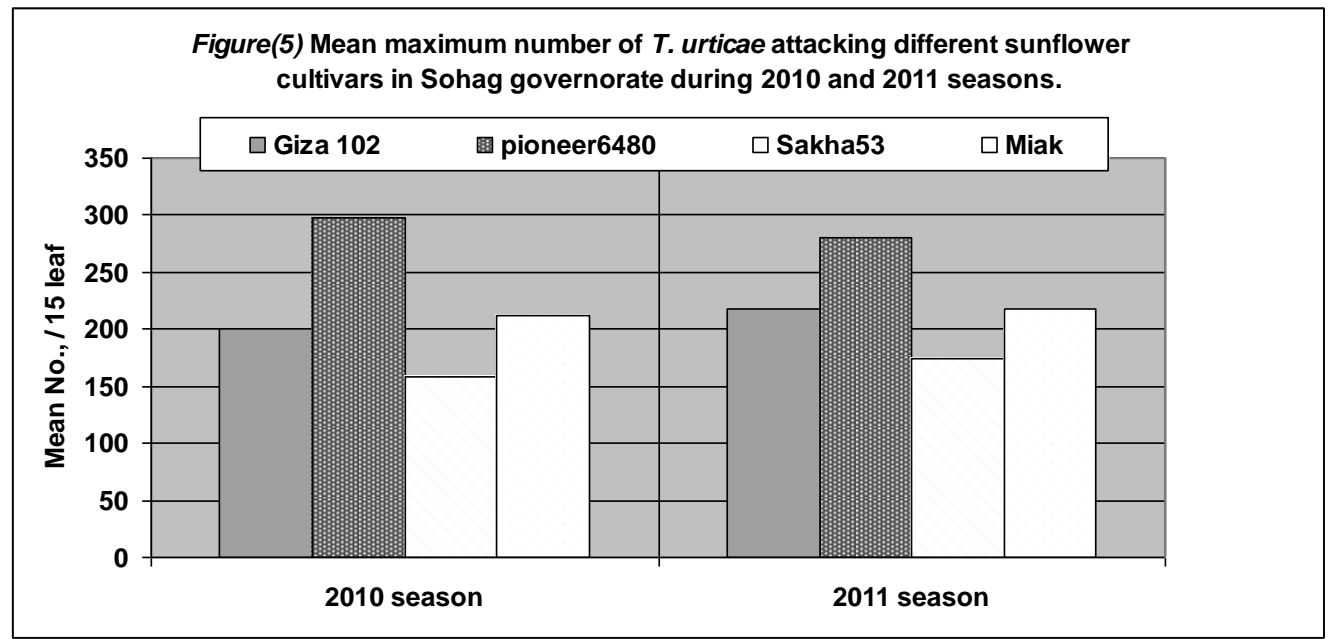

\section{(6): Predator, Euseius hutu:}

In 2010 season, E. hutu. appeared in 16/ June then reached their higher numbers in 14/ July with average numbers of 23.00, 18.33, 20.00 and 21.00 individuals/ 15 sunflower leaflets, respectively. Afterwards, the population disappeared completely in the last two weeks of season Table (6) \& Fig (6).

Table 6. Mean number of Euseius hutu attacking sunflower cultivar, Sohag Governorate, 2010 and 2011 seasons.

\begin{tabular}{|c|c|c|c|c|c|c|c|c|}
\hline \multicolumn{9}{|c|}{ Mean No./ 15 leaflets } \\
\hline \multirow[t]{2}{*}{ Date } & \multicolumn{4}{|c|}{2010 season } & \multicolumn{4}{|c|}{2011 season } \\
\hline & $\begin{array}{c}\text { Giza } \\
102\end{array}$ & $\begin{array}{c}\text { Pionee } \\
\text { r6480 }\end{array}$ & $\begin{array}{c}\text { Sakha } \\
53\end{array}$ & Miak & $\begin{array}{c}\text { Giza } \\
102\end{array}$ & $\begin{array}{c}\text { Pionee } \\
\text { r6480 }\end{array}$ & $\begin{array}{c}\text { Sakha } \\
53\end{array}$ & Miak \\
\hline $\begin{array}{c}\text { Jun } \\
9\end{array}$ & 0.00 & 0.00 & 0.00 & 0.00 & 0.00 & 0.00 & 0.00 & 0.00 \\
\hline 16 & 2.00 & 2.67 & 4.00 & 3.67 & 4.33 & 6.00 & 1.67 & 7.33 \\
\hline 23 & 4.00 & 4.33 & 6.00 & 5.00 & 9.00 & 10.00 & 6.67 & 4.33 \\
\hline 30 & 6.67 & 6.33 & 9.00 & 7.67 & 16.67 & 15.33 & 6.00 & 13.33 \\
\hline $\begin{array}{c}\text { Jul } \\
7\end{array}$ & 12.33 & 8.33 & 13.33 & 11.00 & 33.00 & 30.00 & 23.00 & 28.67 \\
\hline 14 & 23.00 & 18.33 & 20.00 & 21.00 & 20.33 & 17.33 & 12.67 & 16.67 \\
\hline 21 & 2.33 & 3.00 & 2.00 & 2.00 & 3.33 & 3.33 & 1.33 & 4.00 \\
\hline 28 & 0.00 & 0.00 & 0.00 & 0.00 & 0.00 & 0.00 & 0.00 & 0.00 \\
\hline $\begin{array}{c}\text { Aug } \\
4\end{array}$ & 0.00 & 0.00 & 0.00 & 0.00 & 0.00 & 0.00 & 0.00 & 0.00 \\
\hline Mean & 5.59 & 4.78 & 6.04 & 5.59 & 9.63 & 9.11 & 5.70 & 8.26 \\
\hline F-value & \multicolumn{4}{|c|}{2.67} & \multicolumn{4}{|c|}{40.51} \\
\hline $\begin{array}{l}\text { LSD } \\
0.05\end{array}$ & \multicolumn{4}{|c|}{ ns } & \multicolumn{4}{|c|}{0.89} \\
\hline
\end{tabular}




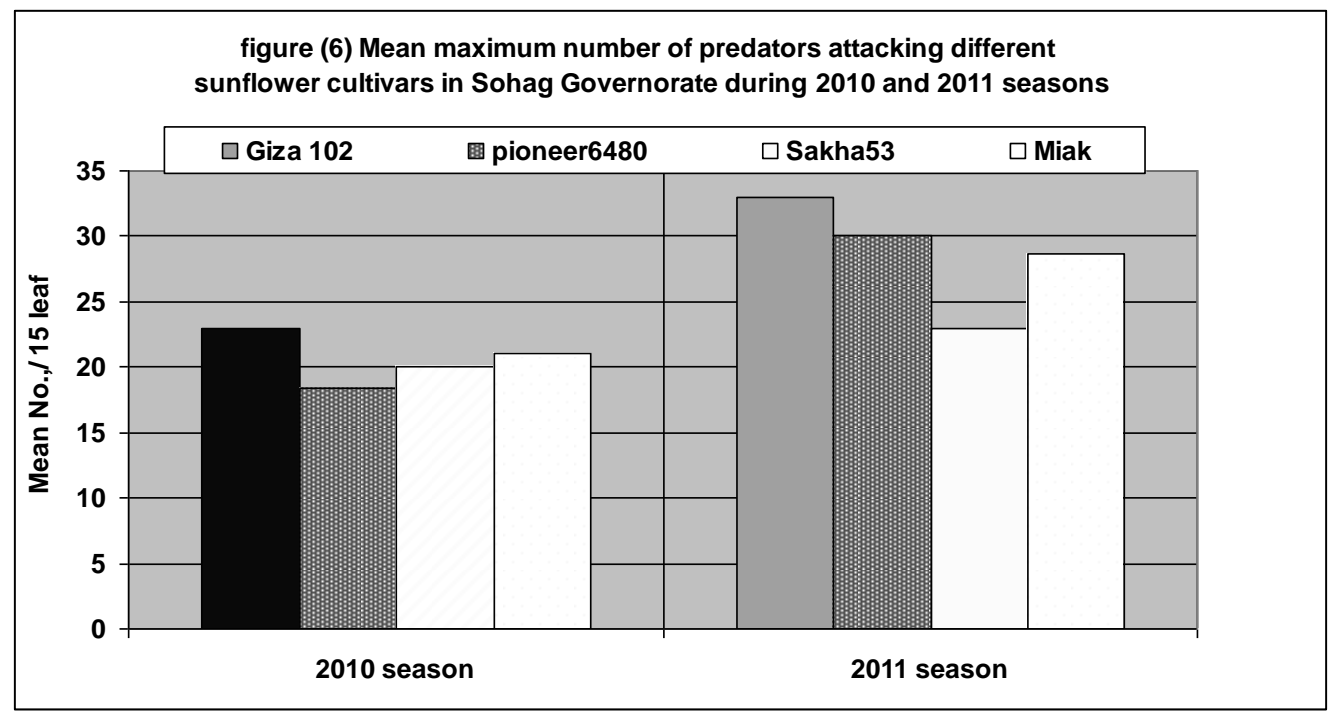

In case of 2011 season, E. hutu also took place in sunflower plots from the second week of inspection, increased gradually to form two peaks in Sakha 53 plots in 23/ June and 7/ July with average numbers of 6.67 and 23.00 individuals/ 15 sunflower leaflets, respectively. For Giza 102, Pioneer6480 and Miak, E. hutu had one peak of activity in $7 /$ July with average numbers of $33.00,30.00$ and 28.67 individuals/ 15 sunflower leaflets, respectively.

This variance in infestation rate of piercing and sucking pests to sunflower varieties may be due to the preference of host selection or the tendency of varieties to tolerant (Ekvised et al., 2006). Therefore, numerous factors appear to be contribute this tendency, including, physical and chemical characters of the plants (Ashoub,1985; Abdel-Gawad, et al.,1987; Abd El-Maksoud, 2008;_El-Shehaby, et al.,1992), environmental effects and genetic resistance (Harvey et al. 1996)

Similarly, the literature on sunflower insects and mites and their resistant to different cultivars has been studied by several investigators included Roger (1992), Ahmed (1996), Charlet et al. (1997), Charlet and Brewer (1998), Charlet (1999), Jyoti and Brewer. (1999), Aslam and Rehman (2000), Mosa, et al. (2001).

Generally, it can be concluded that different peanut genotype varieties could play an important role in integrated pest management program. 


\section{REFERENCES}

1. Abd El-Maksoud, M.F. 2008. Response of two peanut cultivars to row width and hill spaces in sandy soil. Research Journal of Agriculture and Biological Sciences, 4(5): 447-454.

2. Abdel-Gawad A.A., S.A Saleh, M.A. Ashoub and M.M. El-Gazzar. 1987. Factor analysis in yield of certain sunflower cultivars (Helianthus annuus, L.) [Egypt]. Annals of Agricultural Science, Ain Shams Univ. (Egypt) . v. 32(2) p. 1243-1255.

3. Ahmed, M.M. 1996. Resistance in sunflower cultivars to the root-knot nematode, Meloidogyne incognita. Al-Azhar Journal of Agricultural Research. 17 p. 37-42

4. Aslam M. and H. Rehman. 2000. Screening of some sunflower (Helianthus annus L., Compositae) genotypes against insect pests. Pak. J. Bio. Sci, 3:2241-2243.

5. Ashoub, M.A. 1985. Response of sunflower (Helianthus annuus L.). Annals of Agricultural Science, 30(2) p. 1123-1144

6. Mosa, A.A., A.A. El-Deeb and M.M. Ibrahim. 2001. Evaluation of sunflower hybrids for resistance to Sclerotinia sclerotiorum. Annals of Agricultural Science. 45 (2) p. 689-702.

7. Charlet T, L.D. 1999. Biological control of sunflower pests: searching for new parasitoids in native Helianthus- challenges constraints, and potentials, pp. 91112.

8. Charlet, L.D., G.J. Brewer. 1998. Management strategies for insect pests of sunflower in North America, pp. 215-229. In. Recent research developments in entomology. Research Signpost, Trivandrum, India.

9. Charlet, L. D. and J. J. Knodel. 2003. Impact of planting date on sunflower beetle (Coleoptera: Chrysomelidae) infestation, damage, and parasitism in cultivated sunflower. J. Econ. Entomol. 96: 706-713.

10. Charlet, L.D., G.J. Brewer, and B. Franzmann. 1997. Insect pests, pp. 183-261. In.A.A.Schneiter [ed,], sunflower technology and production. Agon. Ser. 35. Am. Soc. Agron., Madiso, WI.

11. El-Shehaby, A.I., I.A. Radwan, M.B. Saoud and M.W. Azab. 1992. Chemical control of some sunflower diseases. Egyptian Journal of Agricultural Research 70(4) p. 1037-1053.

12. Ekvised, S., S. Jogloy, C. Aklasaeng, M. Keerati-Kasikorn, T. Kesmala, I. Buddhasimma and A. Patanothai. 2006. Field evaluation of screening procedures for thrips resistance in peanut. Asian J. Plant Sci., 5: 338-346.

13. Harvey, T. L., D. L. Seifers and K.D. Kofid. 1996. Effect of sorghum hybrid and imidacloprid seed treatment on infestation by corn leaflet aphid and greenbug (Homoptera: Aphididae) and the spread of sugar cane mosaic virus strans, MDMV-B.J. Agric. Entomo. 13(1):9-15.

14. Jyoti, J. L. and G. J. Brewer. 1999. Resistance in sunflower and interaction with Bacillus thuringiensis for control of banded sunflower moth (Lepidoptera: Tortricidae). J. Econ. Entomol. 92: 1230-1233.

15. Roger, C.E. 1992. Insect pests and strategies for their management in cultivated sunflower. Field Crops Res. 30:301-332. 


\title{
حساسية بعض اصناف دوار الثمس للإصابة بالآفات الثاقبة الماصة فى محافظة سوهاج
}

\author{
عزة عبد الجواد محمد و صفاء محد عبد العزيز \\ معرة بحوث وقاية النباتات- مركز البحوث الزراعية - الدقي - الجبزة - مصر
}

تم تقييم قابلية اربعة اصناف من نبات عباد الثمس الأصابة بعض الآفات الثاقبة الماصة

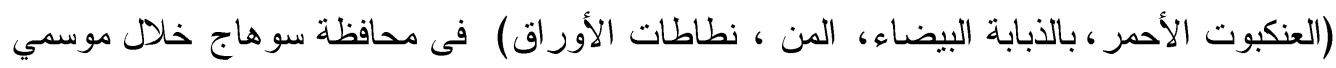

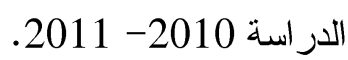

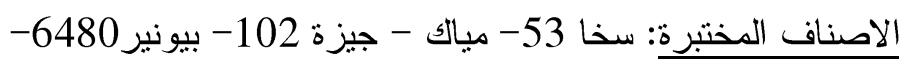

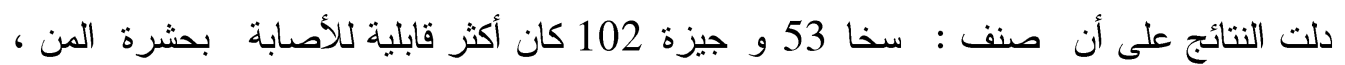

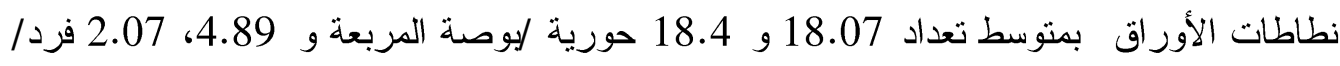

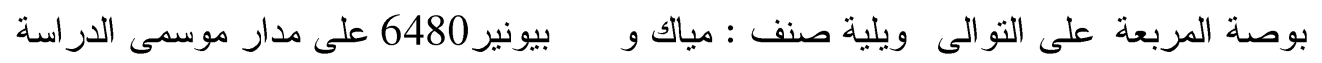
.2011-2010

على الصعيد الأخر وجد أن صنف سخا 53 كان أكثرمقاومة للأصابة بالذبابة البيضاء ويلية صنف :

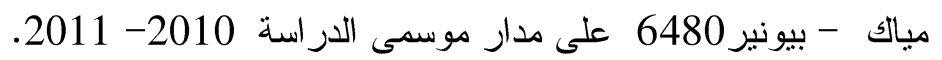

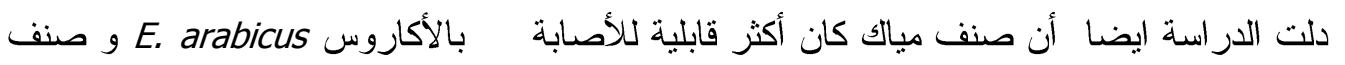

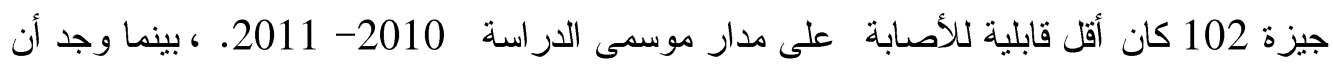

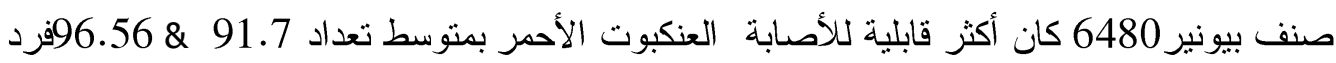

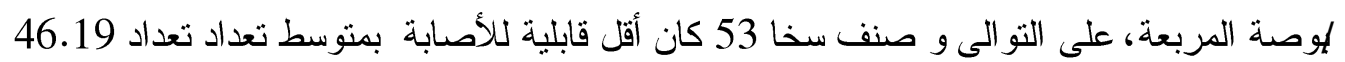

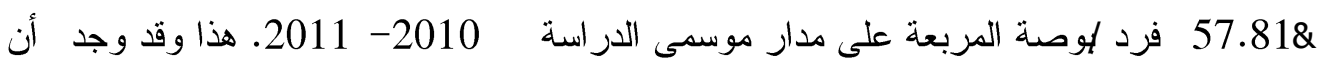

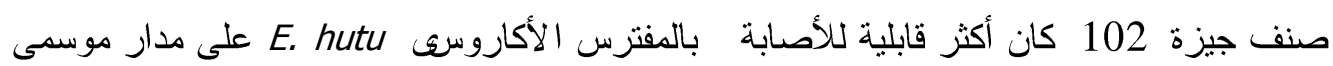
الدراسة 2010- 2011. - 2011. 